OPEN ACCESS

Edited by:

Zhenhai Xia,

University of North Texas,

United States

Reviewed by:

Shichun Mu,

Wuhan University of

Technology, China

Bao Yu Xia

Huazhong University of Science and

Technology, China

*Correspondence:

Jian Guo

guojian@mail.buct.edu.cn

Mingfei Shao

shaomf@mail.buct.edu.cn

tThese authors have contributed equally to this work

Specialty section: This article was submitted to

Energy Materials,

a section of the journa

Frontiers in Materials

Received: 18 August 2019 Accepted: 01 October 2019 Published: 25 October 2019

Citation:

Song Y, Xie W, Li S, Guo J and Shao M (2019) Hierarchical Hollow $\mathrm{Co} / \mathrm{N}-\mathrm{C} @ \mathrm{NiCO}_{2} \mathrm{O}_{4}$ Microsphere as an Efficient Bi-functional Electrocatalyst for Rechargeable Zn-Air Battery.

Front. Mater. 6:261

doi: 10.3389/fmats.2019.0026

\section{Hierarchical Hollow}

\section{$\mathrm{Co} / \mathrm{N}-\mathrm{C} @ \mathrm{NiCO}_{2} \mathrm{O}_{4}$ Microsphere as an Efficient Bi-functional Electrocatalyst for Rechargeable Zn-Air Battery}

\author{
Yuke Song ${ }^{\dagger}$, Wenfu Xie ${ }^{\dagger}$, Shijin Li, Jian Guo* and Mingfei Shao* \\ State Key Laboratory of Chemical Resource Engineering, Beijing University of Chemical Technology, Beijing, China
}

Zn-air batteries (ZABs) have drawn extensive attention for portable and wearable electronic devices owing to their high theoretical specific energy density and low cost. However, due to the dense packing under high mass loading, the mass/charge diffusion is seriously hindered, making their practical performance with high power density, and energy density difficult to sustain. Herein, we reported an efficient bi-functional electrocatalyst of Ni-Co mixed metal oxides incorporated with cobalt/nitrogen-doped carbon with hierarchical hollow nanostructure $\left(\mathrm{H}-\mathrm{Co} / \mathrm{N}-\mathrm{C} @ \mathrm{NiCO}_{2} \mathrm{O}_{4}\right)$. Benefiting from the advantages of this structure and composition, the $\mathrm{H}-\mathrm{Co} / \mathrm{N}-\mathrm{C} @ \mathrm{NiCO}_{2} \mathrm{O}_{4}$ exhibits superior electrocatalytic activity and long-time durability for both oxygen reduction reaction (ORR) and oxygen evolution reaction (OER). The potential gap between half-wave potential in ORR and overpotential at a current density of $10 \mathrm{~mA} \mathrm{~cm} \mathrm{~cm}^{-2}$ in OER reaches $0.8 \mathrm{~V}$, much smaller than that of most reported bi-functional electrocatalysts. Moreover, $\mathrm{H}-\mathrm{Co} / \mathrm{N}-\mathrm{C} @ \mathrm{NiCO}_{2} \mathrm{O}_{4}$ is constructed as an air electrode for rechargeable $\mathrm{ZAB}$, delivering a high power density and long cycling stability. The good linear relationship between the power density and various mass loading of $\mathrm{H}-\mathrm{Co} / \mathrm{N}-\mathrm{C} @ \mathrm{NiCO}_{2} \mathrm{O}_{4}$ on the electrode demonstrates that the performance has been well-maintained even under high dense packing of catalysts, which offers a new pathway for the practical applications in ZAB.

Keywords: bi-functional electrocatalyst, ORR and OER, synergetic effect, hierarchical hollow nanostructure, zinc-air battery

\section{INTRODUCTION}

Zinc-air batteries (ZABs) have been investigated tremendously in past decades owing to their promising theoretical specific energy density of $1,086 \mathrm{Wh} \mathrm{kg}^{-1}$ and low cost, which would meet the ever-increasing energy requirements for renewable energy conversion devices (Lee et al., 2011; Li and Dai, 2014; Chen et al., 2018; Meng et al., 2018; Wang H. F. et al., 2018; Wang T. et al., 2018). Despite these advantages, the sluggish kinetics of oxygen reduction reaction (ORR) and oxygen evolution reaction (OER) during discharging and charging at the air-cathode always result in limited energy and power density of the devices in practical applications (Prabu et al., 2014; Park et al., 2017; Jiang H. et al., 2018; Liu et al., 2019; Qiu et al., 2019). To solve the above problems, a large number of electrocatalysts have been developed for high performance of ORR or OER, such as noble metals (Wu et al., 2010; Audichon et al., 2016), transition metals/metal oxides (Fu et al., 2018; Li T. et al., 2018), and metal-free materials (Ferrero et al., 2016; Hang et al., 2018). 
However, these catalytically active materials generally face issues regarding activities for ORR and OER simultaneously and stabilities (Guo Z. et al., 2018). Thus, exploring highly efficient, stable bi-functional oxygen electrocatalysts is still an urgent task for the ZABs.

Transition metal composites [e.g., oxides (Guan C. et al., 2017; Li Y. et al., 2018; Peng et al., 2018, sulfides (Zhou et al., 2013, 2017b; Ganesan et al., 2015; Zhang et al., 2016), and phosphides (Zhou et al., 2017a; Wu et al., 2018) have been highlighted as attractive candidates for OER electrocatalysts, but they fail to catalyze the ORR process. Recently, heteroatom-doped carbon materials expressed excellent electrocatalytic activity for ORR, where Co-N-C has been regarded as one of the best candidates for ORR and Zn-air batteries (Zhao et al., 2012; Shang et al., 2016; Amiinu et al., 2018; Guo Y. et al., 2018; Jiang R. et al., 2018; Wang T. et al., 2018; Wang Z. et al., 2018; Liang et al., 2019). Being inspired by this, assembling transition metal oxides with heteroatom-doped carbon materials is an effective approach to obtain bi-functional electrocatalysts for both OER and ORR (Guo Z. et al., 2018). However, in practice, the performance of electrocatalysts under high mass loading is difficult to maintain due to the agglomeration of particles that severely inhibits mass/charge diffusion process, which has so far been few considered (Xie et al., 2019). Therefore, it is desirable to construct advanced electrodes with more sophisticated functionalities, so as to boost mass transfer process and more exposed active sites under high catalyst loading.

Herein, we demonstrate a bi-functional electrocatalyst with well-ordered hierarchical hollow nanostructure, which shows high performances for both the ORR and OER even under high mass loading. The bi-functional hollow structured electrocatalyst consisting of cobalt/nitrogen-doped carbon embedded with $\mathrm{Ni}$ $\mathrm{Co}$ mixed metal oxides $\left(\mathrm{H}-\mathrm{Co} / \mathrm{N}-\mathrm{C} @ \mathrm{NiCo}_{2} \mathrm{O}_{4}\right)$ is prepared via a facile self-template approach. Benefiting from the advantages of this structure and composition, the as-synthesized $\mathrm{H}-\mathrm{Co} / \mathrm{N}-$ $\mathrm{C@NiCo} 2 \mathrm{O}_{4}$ exhibits impressive electrocatalytic activity and long-time durability for both ORR and OER. In addition, the advanced $\mathrm{H}-\mathrm{Co} / \mathrm{N}-\mathrm{C} @ \mathrm{NiCo}_{2} \mathrm{O}_{4}$ is constructed as an air cathode for rechargeable $\mathrm{ZAB}$, which delivers a high power density and long cycling stability. The good linear relationship between the power density and various mass loading of $\mathrm{H}-\mathrm{Co} / \mathrm{N}-\mathrm{C} @ \mathrm{NiCo}_{2} \mathrm{O}_{4}$ on the electrode demonstrates that the performance has been well-maintained even under high dense packing of catalysts, which offers a new pathway for the practical applications in $\mathrm{ZAB}$.

\section{EXPERIMENTAL SECTION}

\section{Synthesis of PS@ZIF-67 Microsphere Template}

Firstly, the polystyrene (PS) microsphere was synthesized using a method of dispersion polymerization (Lee et al., 2006). Then, the synthesized PS $(0.25 \mathrm{~g})$ and $\mathrm{Co}\left(\mathrm{NO}_{3}\right)_{2} \cdot 6 \mathrm{H}_{2} \mathrm{O}(2.25 \mathrm{~g})$ were dispersed in methanol $(150 \mathrm{ml})$. Then, $150 \mathrm{ml}$ of methanol solution containing $6.225 \mathrm{~g}$ of 2-methylimidazole was quickly added into the former dispersion. After stirring at room temperature for $1 \mathrm{~h}$, the products were washed with methanol and dried overnight.

\section{Synthesis of PS@ZIF-67@NiCo-LDH and PS@NiCo-LDH}

Firstly, $0.2 \mathrm{~g}$ of PS@ZIF-67 was dispersed in $100 \mathrm{ml}$ of ethanol. Then, $25 \mathrm{ml}$ of ethanol solution containing $0.45 \mathrm{~g}$ of $\mathrm{Ni}\left(\mathrm{NO}_{3}\right)_{2} \cdot 6 \mathrm{H}_{2} \mathrm{O}$ was quickly poured into the former dispersion. After stirring at room temperature for $0.5 \mathrm{~h}$, the products were washed with ethanol and dried overnight. The products were denoted as PS@ZIF-67@NiCo-LDH. Besides, PS@NiCo-LDH was also synthesized by using the above procedures but stirring for $4 \mathrm{~h}$.

\section{Synthesis of $\mathrm{H}-\mathrm{Co} / \mathrm{N}-\mathrm{C}$, $\mathrm{H}-\mathrm{Co} / \mathrm{N}-\mathrm{C} @ \mathrm{NiCO}_{2} \mathrm{O}_{4}$, and $\mathrm{H}-\mathrm{NiCo}_{2} \mathrm{O}_{4}$}

The as-prepared PS@ZIF-67, PS@ZIF-67@NiCo-LDH, and PS@NiCo-LDH were pyrolyzed in $\mathrm{N}_{2}$ at $600^{\circ} \mathrm{C}$ for $2 \mathrm{~h}$. The products were denoted as $\mathrm{H}-\mathrm{Co} / \mathrm{N}-\mathrm{C}, \mathrm{H}-\mathrm{Co} / \mathrm{N}-\mathrm{C} @ \mathrm{NiCo}_{2} \mathrm{O}_{4}$, and $\mathrm{H}-\mathrm{NiCo}_{2} \mathrm{O}_{4}$, respectively.

\section{Characterization}

X-ray diffraction patterns were obtained on a Shimadzu XRD-6000 diffractometer with $\mathrm{Cu} \mathrm{K} \alpha$ radiation. Scanning electron microscope (SEM) was obtained on Zeiss Supra 55. Elemental mapping and EDS were recorded using energydispersive X-ray spectroscopy (EDS) attached to the SEM. High-resolution transmission electron microscope (HRTEM) was performed on JEOL JEM-2010. X-ray photoelectron spectra (XPS) were collected using a Thermo VG ESCALAB 250. Raman spectra were carried out by HORIBA Jobin Yvon Raman microspectrometer. $\mathrm{N}_{2}$ adsorption/desorption isotherms were investigated using an Micromeritics ASAP 2020 instrument at $77 \mathrm{~K}$.

\section{Electrochemical Measurements}

All electrochemical tests were carried out on an electrochemical workstation (CHI 760E, Shanghai Chenhua, China). A glassy carbon (GC) or carbon cloth with catalysts, Pt wire, and $\mathrm{Ag} / \mathrm{AgCl}$ electrode were used as working electrode, counter electrode, and reference electrode, respectively. The catalyst inks were prepared as follows: $5.89 \mathrm{mg}$ catalyst was ultrasonically dispersed in $770 \mu \mathrm{l}$ of deionized water, $200 \mu \mathrm{l}$ of ethanol, and $30 \mu \mathrm{l}$ of Nafion solution (5 wt\%). For the ORR tests, the as-prepared catalyst ink was pipetted onto the rotating disk electrode (RDE, $\left.0.196 \mathrm{~cm}^{2}\right)$ and ring rotating disk electrode (RRDE, carbon disk with a surface area of $0.126 \mathrm{~cm}^{2}$ surrounded by a Pt ring with a surface area of $0.224 \mathrm{~cm}^{2}$ ) with a loading of $0.3 \mathrm{mg} \mathrm{cm}^{-2}$, and dried under room temperature. Cyclic voltammetry $(\mathrm{CV})$ was tested in $\mathrm{O}_{2}$ and $\mathrm{N}_{2}$-saturated $0.1 \mathrm{M} \mathrm{KOH}$ at a scan rate of $100 \mathrm{mV} \mathrm{s}^{-1}$. The following tests were obtained in $\mathrm{O}_{2}$-saturated $0.1 \mathrm{M} \mathrm{KOH}$. $\mathrm{RDE}$ tests were carried out at various rotation rates from 400 to 2,025 $\mathrm{rpm}$ with a scan rate of $5 \mathrm{mV} \mathrm{s}^{-1}$. RRDE measurements were also conducted in $\mathrm{O}_{2}$-saturated $0.1 \mathrm{M} \mathrm{KOH}$ at room temperature. The disk potential was scanned from -1 to $0.2 \mathrm{~V}$ at a scan rate of $5 \mathrm{mV}$ $\mathrm{s}^{-1}$ and the ring potential was constant at $0.5 \mathrm{~V}$. The stability tests were measured by $i-t$ amperometric response at $0.16 \mathrm{~V}$ vs. 
RHE. RRDE tests, electrochemical impedance spectra (EIS), and $i-t$ amperometic response were all measured at atation rate of $1,600 \mathrm{rpm}$. The electrical double-layer capacitance $\left(C_{d l}\right)$ of the catalysts was performed using $\mathrm{CV}$ at different scan rates from 20 to $120 \mathrm{mV} \mathrm{s}^{-1}$ in non-Faradaic region. For the OER tests, the catalyst ink was pipetted onto carbon cloth with a loading of $1 \mathrm{mg} \mathrm{cm}^{-2}$, and dried under room temperature. Linear sweep voltammetry (LSV) was measured in $1 \mathrm{M} \mathrm{KOH}$ at a scan rate of $5 \mathrm{mV} \mathrm{s}^{-1}$ under stirring (90\% $i R$-compensation).

The potential vs. reversible hydrogen electrode (RHE) was calculated via the Nernst equation:

$$
E_{R H E}=E_{A g / A g C l}+0.059 p H+0.197
$$

The overpotential $(\eta)$ was calculated using the following formula:

$$
\eta(\mathrm{V})=E_{R H E}-1.23 \mathrm{~V}
$$

The electron transfer number $(n)$ was calculated according the Koutecky-Levich equation:

$$
\begin{aligned}
\frac{1}{j} & =\frac{1}{j_{L}}+\frac{1}{j_{K}}=\frac{1}{B \omega^{1 / 2}}+\frac{1}{j_{K}} \\
B & =0.62 n F C_{0} D_{0}^{2 / 3} v^{-1 / 6}
\end{aligned}
$$

where $j, j_{L}$, and $j_{K}$ are the measured current density, diffusionlimiting current density, and kinetic current density, respectively; $\omega$ is the rate of electrode rotation speed; $F$ is the Faraday constant $\left(96,485 \mathrm{C} \mathrm{mol}^{-1}\right) ; C_{0}$ is the bulk concentration of $\mathrm{O}_{2}(1.26 \times$ $\left.10^{-6} \mathrm{~mol} \mathrm{~cm}^{-3}\right) ; D_{0}$ is the diffusion coefficient of $\mathrm{O}_{2}$ in $0.1 \mathrm{M}$ $\mathrm{KOH}\left(1.9 \times 10^{-5} \mathrm{~cm}^{2} \mathrm{~s}^{-1}\right) ; v$ is the kinematic viscosity of electrolyte $\left(0.01 \mathrm{~cm}^{2} \mathrm{~s}^{-1}\right)$.

For the RRDE measurements, the percentage of hydrogen peroxide yield $\mathrm{HO}_{2}^{-}(\%)$ and the electron transfer number $(n)$ were calculated using the following formula:

$$
\begin{aligned}
H O_{2}^{-}(\%) & =200 \frac{I_{r} / N}{I_{d}+I_{r} / N} \\
n & =4 \frac{I_{d}}{I_{d}+I_{r} / N}
\end{aligned}
$$

where $I_{d}$ and $I_{r}$ are the disk and ring currents, respectively; $N$ is the ring collection efficiency determined to be 0.37 .

The difference in current density $\left(\Delta j=j_{\mathrm{a}}-j_{\mathrm{c}}\right)$ at $0.46 \mathrm{~V}$ vs. RHE was plotted against scan rate and fitted to a linear regression for the estimation of double layer capacitances $\left(C_{d l}\right)$.

$$
C_{d l}=\frac{\text { slope of regression line }}{2}
$$

The Tafel slope was calculated by the following formula:

$$
\eta=a+b \log |j|
$$

where $\eta$ is the overpotential; $b$ is the Tafel slope; $j$ is the current density.

\section{Zn-Air Battery Tests}

All $\mathrm{Zn}$-air battery tests were carried out on an electrochemical workstation (CHI 660E, Shanghai Chenhua, China). A carbon cloth loaded with the catalyst inks $\left(1 \mathrm{mg} \mathrm{cm}^{-2}\right)$ served as the air cathode, and a polished $\mathrm{Zn}$ foil served as the anode. For the rechargeable $\mathrm{Zn}$-air batteries, $6 \mathrm{M} \mathrm{KOH}$ and $0.2 \mathrm{M}$ $\mathrm{Zn}\left(\mathrm{CH}_{3} \mathrm{COO}\right)_{2}$ were chosen as the electrolyte. The polarization curves were measured at a scan rate of $5 \mathrm{mV} \mathrm{s}^{-1}$. The galvanostatic charge and discharge cycling curves were measured at a current density of $5 \mathrm{~mA} \mathrm{~cm} \mathrm{~cm}^{-2}$ (discharge $100 \mathrm{~s}$ and charge 100 s). Specifically, discharging polarization curves at a current density of $10 \mathrm{~mA} \mathrm{~cm}^{-2}$ were measured in $6 \mathrm{M} \mathrm{KOH}$.

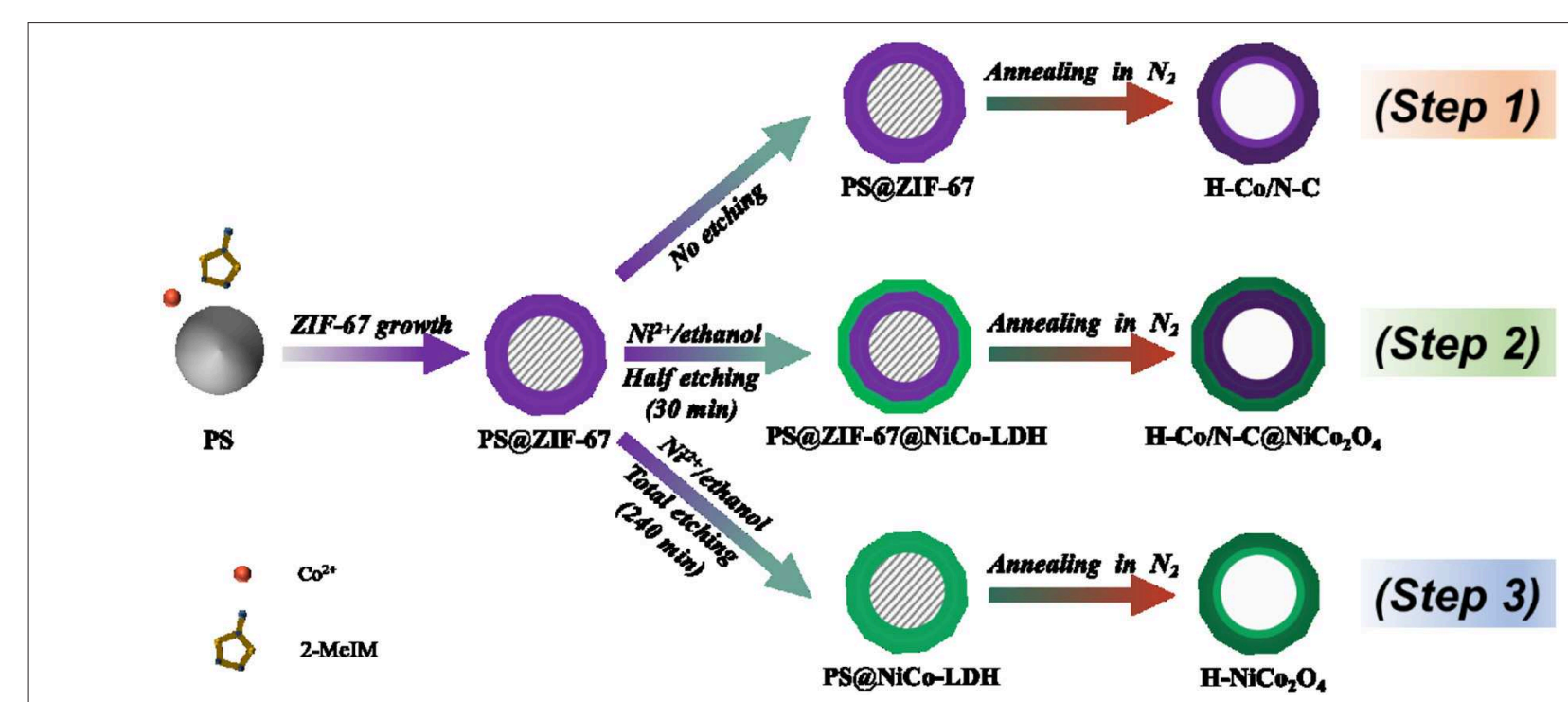

SCHEME 1 | A schematic illustration for the synthesis of $\mathrm{H}-\mathrm{Co} / \mathrm{N}-\mathrm{C} @ \mathrm{NiCO}_{2} \mathrm{O}_{4}$. 
The power density, specific capacity, and energy density were calculated by the following formula:

$$
\begin{aligned}
& \text { Power density }\left(\mathrm{mW} \mathrm{cm}^{-2}\right)=\text { current density } \times \text { voltage } \\
& \text { Specific capacity }\left(\mathrm{mAh} \mathrm{g}^{-1}\right)=\frac{\text { current } \times \text { service hours }}{\text { weight of consumed } \mathrm{Zn}} \\
& \text { Energy density }\left(\mathrm{Wh} \mathrm{kg}^{-1}\right) \\
& =\frac{\text { current } \times \text { service hours } \times \text { average discharge voltage }}{\text { weight of consumed } \mathrm{Zn}}
\end{aligned}
$$

\section{RESULTS AND DISCUSSION}

\section{Material Characterizations}

The synthesis process of hollow Co/N-C@NiCo $\mathrm{O}_{4}$ microspheres (H-Co/N-C@NiCo $\left.2 \mathrm{O}_{4}\right)$ is illustrated in Scheme 1 (Step 2, see the Experimental Section for details). First, PS microspheres with an average size of $2.7 \mu \mathrm{m}$ were synthesized via a dispersion polymerization process (Figure 1a). Second, zeolitic imidazolate framework (ZIF-67) nanoparticles were compactly assembled on the surface of PS to obtain PS@ZIF-67 microspheres (Figures 1b, 2A). The growth mechanism of ZIF-67 on the surface of PS microsphere is supposed to be the nucleation growth mechanism (Guan B. Y. et al., 2017). Typically, Co ions first coordinate with the carboxylate on the surface of PS microsphere. Then, 2-methylimidazole connects with the Co ions and leads to the in situ nucleation process and the growth of ZIF-67 nanoparticles. Third, the obtained PS@ZIF-67 microspheres were in situ converted into PS@ZIF-67@NiCo-LDH microspheres by reacting with $\mathrm{Ni}\left(\mathrm{NO}_{3}\right)_{2}$ in ethanol solution for $30 \mathrm{~min}$ (Figure 1c). After that, the ZIF-67 nanoparticles with a dodecahedral shape partly dissolved and lots of nanosheets were aligned on the surface of microspheres, which derived a unique architecture of honeycomb with yolk-shelled structure. Last, a thermal treatment was performed to obtain hollow and hierarchical $\mathrm{Co} / \mathrm{N}-\mathrm{C} @ \mathrm{NiCo}_{2} \mathrm{O}_{4}$ microspheres (Figure 1d). After thermal treatment, the structure of microspheres is maintained while the average size of microspheres is decreased from 3.1 to $2.8 \mu \mathrm{m}$ due to the contraction of ZIF-67. TEM image reveals that hollow cavities are formed inside $\mathrm{H}-\mathrm{Co} / \mathrm{N}-\mathrm{C} @ \mathrm{NiCo}_{2} \mathrm{O}_{4}$ microspheres as a result of volatilization of PS (Figure 1e), which would facilitate the electrolyte penetration. High-resolution TEM image shows that lots of nanoparticles with an interlayer spacing of 4.7 and $2.9 \AA$ dispersed on the surface of microsphere, corresponding to the (111) and (220) plane of $\mathrm{NiCo}_{2} \mathrm{O}_{4}$ (Zhang and Lou, 2013), which are derived from NiCo-LDH (Figure 1f). Other nanoparticles embedded in graphite-like layers with an interlayer spacing of $2.1 \AA$ correspond to the (111) plane of Co metal (Aijaz et al., 2016). Moreover, the EDS elemental mapping of $\mathrm{H}-\mathrm{Co} / \mathrm{N}-\mathrm{C} @ \mathrm{NiCo}_{2} \mathrm{O}_{4}$ displays a well-uniformed distribution of $\mathrm{C}, \mathrm{N}, \mathrm{O}, \mathrm{Co}$, and $\mathrm{Ni}$, confirming the successful introduction of $\mathrm{Ni}$ during the etching process

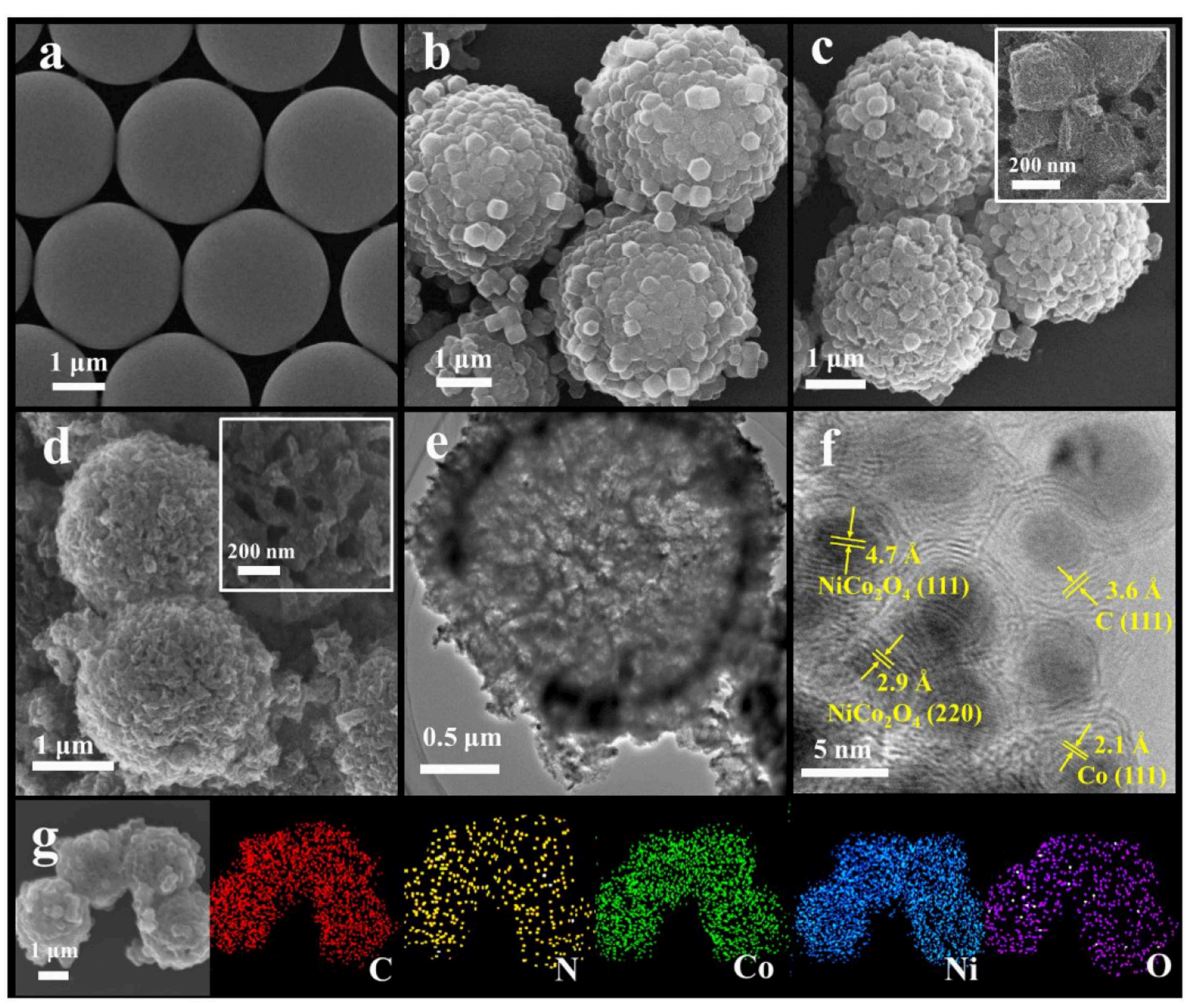

FIGURE 1 | SEM images of (a) PS microspheres, (b) PS@ZIF-67 microspheres, (c) PS@ZIF-67@NiCo-LDH microspheres, and (d) $\mathrm{H}-\mathrm{Co} / \mathrm{N}-\mathrm{C} @ \mathrm{NiCO} 2 \mathrm{O}_{4}$. (e) TEM and (f) HRTEM image of $\mathrm{H}-\mathrm{Co} / \mathrm{N}-\mathrm{C} @ \mathrm{NiCO}_{2} \mathrm{O}_{4}$. (g) SEM and EDS elemental mapping images of $\mathrm{H}-\mathrm{Co} / \mathrm{N}-\mathrm{C} @ \mathrm{NiCO}_{2} \mathrm{O}_{4}$. 

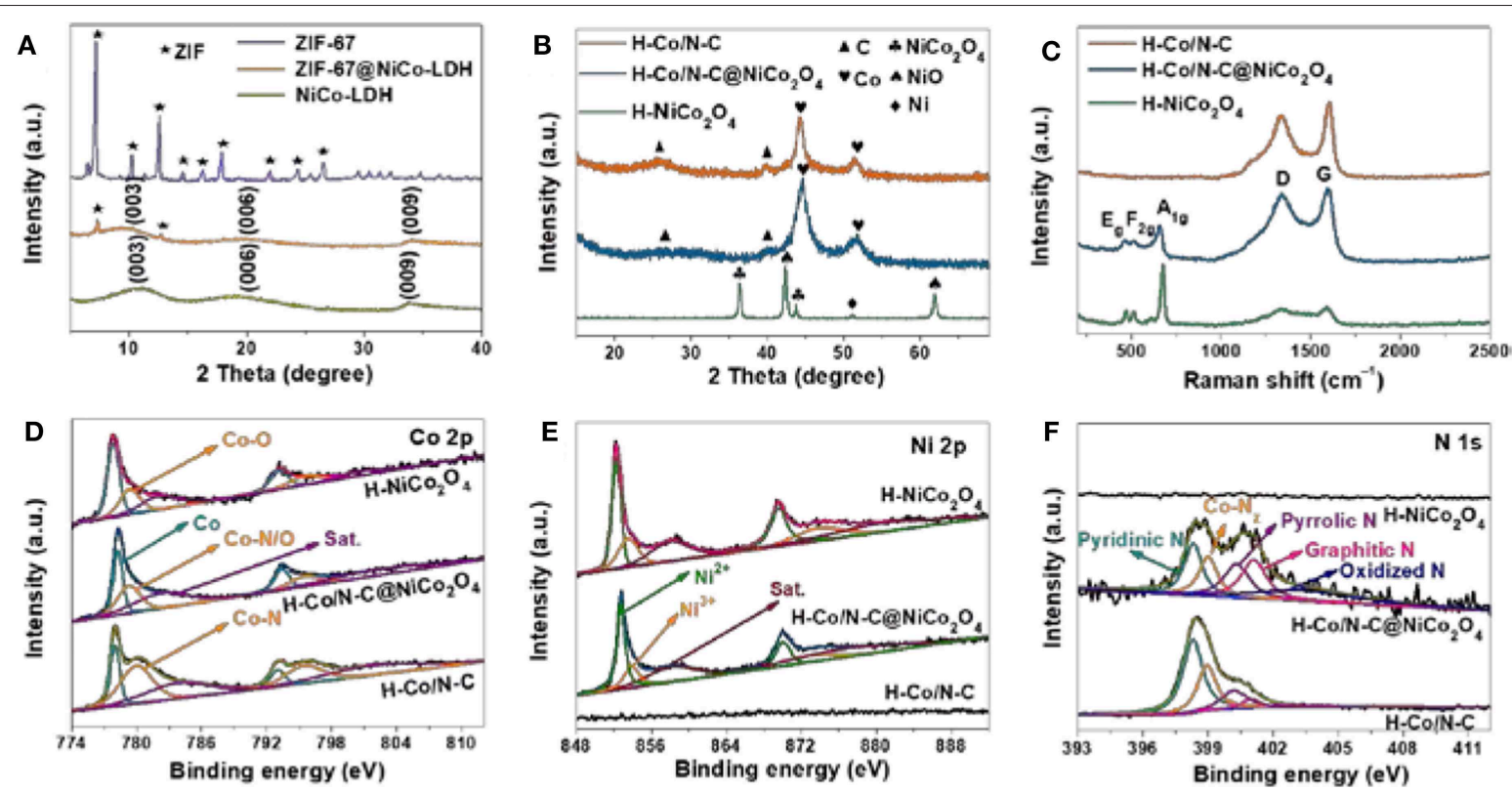

FIGURE 2 | (A) XRD patterns of PS@ZIF-67, PS@ZIF-67@NiCo-LDH, and PS@NiCo-LDH. (B) XRD patterns, (C) Raman spectra, high-resolution XPS spectra of (D) $\mathrm{Co} 2 p$, (E) Ni 2p, and (F) N 1s for $\mathrm{H}-\mathrm{Co} / \mathrm{N}-\mathrm{C}, \mathrm{H}-\mathrm{Co} / \mathrm{N}-\mathrm{C} @ \mathrm{NiCO}_{2} \mathrm{O}_{4}$ and $\mathrm{H}-\mathrm{NiCo}_{2} \mathrm{O}_{4}$.

(Figure 1g and Figure S5). During the etching process, ZIF-67 could be completely etched away when the etching time is prolonged to $4 \mathrm{~h}$ and the product noted is as PS@NiCo-LDH [Scheme 1 (Step 3), Figures S1a, S2]. After thermal treatment, PS@NiCo-LDH is in situ transformed into hollow $\mathrm{NiCo}_{2} \mathrm{O}_{4}$ microspheres (denoted as $\mathrm{H}-\mathrm{NiCo}_{2} \mathrm{O}_{4}$ ) (Figures $\mathrm{S} 1 \mathbf{b}, \mathbf{c}$ ). In addition, hollow Co, $\mathrm{N}$-doped carbon microspheres (denoted as $\mathrm{H}-\mathrm{Co} / \mathrm{N}-\mathrm{C}$ ) without $\mathrm{NiCo}_{2} \mathrm{O}_{4}$ obtained by direct pyrolysis of PS@ZIF-67 was also synthesized as reference [Scheme 1 (Step 1); Figures S3, S4].

XRD analysis of ZIF-67@NiCo-LDH indicates that ZIF-67 is successfully transformed into $\mathrm{NiCo}-\mathrm{LDH}$, from which the peaks of ZIF-67 are transformed into three peaks at $\sim 11^{\circ}, 20^{\circ}$, and $34^{\circ}$, attributed to the (003), (006), and (009) planes of $\mathrm{LDH}$ (Li et al., 2015; Kaneti et al., 2017) (Figure 2A). After thermal treatment, the diffraction patterns of $\mathrm{H}-\mathrm{Co} / \mathrm{N}-\mathrm{C} @ \mathrm{NiCo}_{2} \mathrm{O}_{4}$ and $\mathrm{H}-\mathrm{Co} / \mathrm{N}-\mathrm{C}$ show that two well-defined diffraction peaks that emerged at $44.3^{\circ}$ and $51.7^{\circ}$ correspond to the (111) and (200) planes of face-centered Co (JCPDS15-0806), and the peaks at $26.1^{\circ}$ and $44.6^{\circ}$ are indexed to the (002) and (111) planes of graphitic carbon ( $\mathrm{Li}$ J. et al., 2018). The diffraction pattern of $\mathrm{H}-\mathrm{NiCo}_{2} \mathrm{O}_{4}$ implies the presence of $\mathrm{NiCo}_{2} \mathrm{O}_{4}$ (PDF\#731702), $\mathrm{NiO}$ (PDF\#89-7390), and $\mathrm{Ni}$ (PDF\#70-0989). It should be mentioned that the diffraction peak of $\mathrm{NiCo}_{2} \mathrm{O}_{4}$ is not observed in $\mathrm{H}-\mathrm{Co} / \mathrm{N}-\mathrm{C} @ \mathrm{NiCo}_{2} \mathrm{O}_{4}$ due to the high peak intensity of Co (Figure 2B). The graphitic feature and defects of synthesized materials were investigated by Raman spectra (Figure 2C). The intensity ratio of the $\mathrm{D}$ band $\left(1340 \mathrm{~cm}^{-1}\right)$ to the $\mathrm{G}$ band $(1590$ $\left.\mathrm{cm}^{-1}\right)\left(I_{\mathrm{D}} / I_{\mathrm{G}}\right)$ for $\mathrm{H}-\mathrm{Co} / \mathrm{N}-\mathrm{C} @ \mathrm{NiCo}_{2} \mathrm{O}_{4}(0.95)$ is higher than $\mathrm{H}-\mathrm{Co} / \mathrm{N}-\mathrm{C}(0.83)$, indicating that $\mathrm{H}-\mathrm{Co} / \mathrm{N}-\mathrm{C} @ \mathrm{NiCo}_{2} \mathrm{O}_{4}$ contains more defective carbon, which is beneficial to the improvement of electrocatalytic activity (Zhang et al., 2011; Chen et al., 2017; Yang et al., 2017; Asset et al., 2018). Besides, there are three peaks at $463 \mathrm{~cm}^{-1}$ ( $\mathrm{E}_{\mathrm{g}}$ mode), $507 \mathrm{~cm}^{-1}\left(\mathrm{~F}_{2 \mathrm{~g}}\right.$ mode), and 663 $\mathrm{cm}^{-1}\left(\mathrm{~A}_{1 \mathrm{~g}}\right.$ mode) in $\mathrm{H}-\mathrm{Co} / \mathrm{N}-\mathrm{C} @ \mathrm{NiCo}_{2} \mathrm{O}_{4}$ and $\mathrm{H}-\mathrm{NiCo}_{2} \mathrm{O}_{4}$, corresponding to $\mathrm{Co}-\mathrm{O}$ and $\mathrm{Ni}-\mathrm{O}$ molecular vibration peaks of $\mathrm{NiCo}_{2} \mathrm{O}_{4}$ (Umeshbabu et al., 2015).

The X-ray photoelectron spectroscopy (XPS) spectra confirm the presence of $\mathrm{C}, \mathrm{N}, \mathrm{O}, \mathrm{Co}$, and $\mathrm{Ni}$ in $\mathrm{H}-\mathrm{Co} / \mathrm{N}-$ $\mathrm{C@NiCo} \mathrm{O}_{4}$ (Figure S6 and Table S1). The Co 2p spectrum demonstrates the presence of both zero valence state (777.8 and $793.1 \mathrm{eV}$ ) and oxidation state $(779.3$ and $795.6 \mathrm{eV}) \mathrm{Co}$ species, which can be assigned to the metallic Co and Co$\mathrm{N} / \mathrm{O}_{\chi}$ coordination, respectively ( $\mathrm{Ni}$ et al., 2017) (Figure 2D). For the $\mathrm{Ni} 2 \mathrm{p}$ spectrum of $\mathrm{H}-\mathrm{Co} / \mathrm{N}-\mathrm{C} @ \mathrm{NiCo}_{2} \mathrm{O}_{4}$ and $\mathrm{H}$ $\mathrm{NiCo}_{2} \mathrm{O}_{4}$, the peaks located at $852.2 / 869.5$ and $853.7 / 873.9 \mathrm{eV}$ correspond to $\mathrm{Ni}^{3+}$ and $\mathrm{Ni}^{2+}$, respectively (Cui et al., 2009) (Figure 2E). The $\mathrm{N} 1 \mathrm{~s}$ peak of $\mathrm{H}-\mathrm{Co} / \mathrm{N}-\mathrm{C} @ \mathrm{NiCo}_{2} \mathrm{O}_{4}$ is deconvoluted into five types of $\mathrm{N}$ species, namely, pyridinic $(398.5 \mathrm{eV})$, Co- $\mathrm{N}_{\chi}(399.6 \mathrm{eV})$, pyrrolic $(400.5 \mathrm{eV})$, graphitic $(401.0 \mathrm{eV})$, and oxidized $(403.7 \mathrm{eV}) \mathrm{N}$ species (Jia et al., 2017) (Figure 2F). There is no $\mathrm{N} 1 \mathrm{~s}$ peak in $\mathrm{H}-\mathrm{NiCo}_{2} \mathrm{O}_{4}$, indicating that ZIF-67 is completely removed by etching. The surface area and pore size distribution of $\mathrm{H}-\mathrm{Co} / \mathrm{N}-\mathrm{C}$, $\mathrm{H}-\mathrm{Co} / \mathrm{N}-\mathrm{C} @ \mathrm{NiCo}_{2} \mathrm{O}_{4}$, and $\mathrm{H}-\mathrm{NiCo}_{2} \mathrm{O}_{4}$ are investigated by $\mathrm{N}_{2}$-adsorption/desorption isotherms (Figure S7). The type IV isotherms with $\mathrm{H}_{3}$-type hysteresis loops are observed for all samples, indicating the existence of mesopores ( $\mathrm{Li}$ et al., 2016; Zhan and Zeng, 2017). Although the specific surface area of $\mathrm{H}-\mathrm{Co} / \mathrm{N}-\mathrm{C} @ \mathrm{NiCo}_{2} \mathrm{O}_{4}$ is the smallest, it exhibits the best electrocatalytic performance in subsequent electrochemical tests, indicating that the synergy between $\mathrm{Co} / \mathrm{N}-\mathrm{C}$ and 

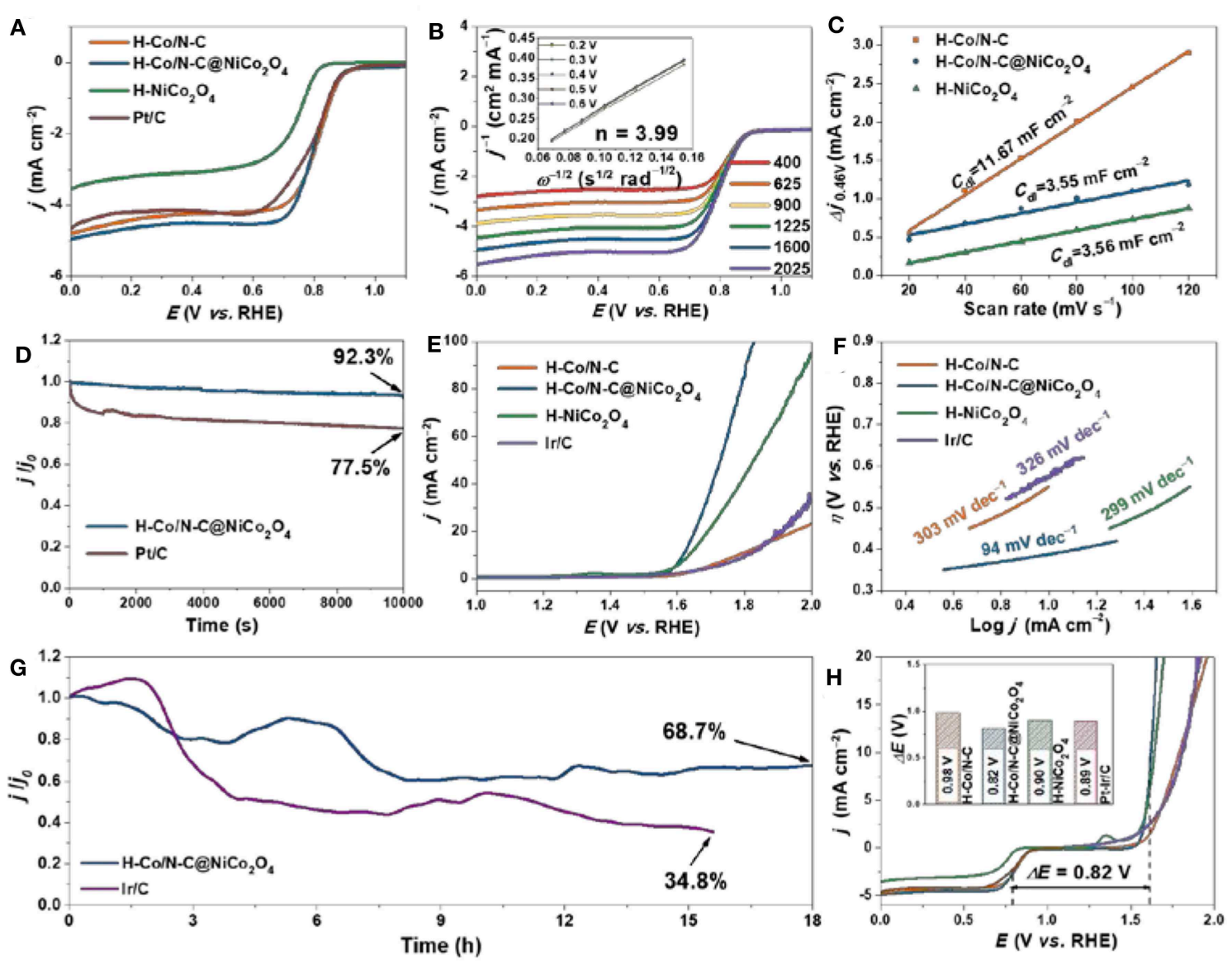

FIGURE 3 | (A) LSV curves of $\mathrm{H}-\mathrm{Co} / \mathrm{N}-\mathrm{C}, \mathrm{H}-\mathrm{Co} / \mathrm{N}-\mathrm{C} @ \mathrm{NiCO}_{2} \mathrm{O}_{4}, \mathrm{H}-\mathrm{NiCO}_{2} \mathrm{O}_{4}$, and $\mathrm{Pt} / \mathrm{C}$ for ORR. (B) LSV curves for $\mathrm{H}-\mathrm{Co} / \mathrm{N}-\mathrm{C} @ \mathrm{NiCO}_{2} \mathrm{O}_{4}$ at various rotation rates. The inset is the corresponding Kouteck-Levich plots for $\mathrm{H}-\mathrm{Co} / \mathrm{N}-\mathrm{C} @ \mathrm{NiCO}_{2} \mathrm{O}_{4}$ at various potentials calculated from RDE data. (C) $\mathrm{C}_{d l}$ of $\mathrm{H}-\mathrm{Co} / \mathrm{N}-\mathrm{C}, \mathrm{H}-\mathrm{Co} / \mathrm{N}-\mathrm{C} @ \mathrm{NiCO} \mathrm{O}_{4}$, and $\mathrm{H}-\mathrm{NiCO}_{2} \mathrm{O}_{4}$ calculated from current density difference $\left(\Delta j=j_{\mathrm{a}}-j_{\mathrm{c}}\right)$ plotted vs. scan rate. (D) Amperometric $i-t$ curves of $\mathrm{H}-\mathrm{Co} / \mathrm{N}-\mathrm{C} @ \mathrm{NiCO} \mathrm{O}_{4}$ and $\mathrm{Pt} / \mathrm{C}$ for ORR. (E) LSV curves and (F) Tafel slopes of $\mathrm{H}-\mathrm{Co} / \mathrm{N}-\mathrm{C}, \mathrm{H}-\mathrm{Co} / \mathrm{N}-\mathrm{C} @ \mathrm{NiCo}_{2} \mathrm{O}_{4}, \mathrm{H}-\mathrm{NiCO}_{2} \mathrm{O}_{4}$, and Ir/C for OER. (G) Amperometric $i-t$ curves of $\mathrm{H}-\mathrm{Co} / \mathrm{N}-\mathrm{C} @ \mathrm{NiCO} \mathrm{O}_{4}$ and Ir/C for OER. (H) Overall LSV curves of the ORR and OER for $\mathrm{H}-\mathrm{Co} / \mathrm{N}-\mathrm{C}, \mathrm{H}-\mathrm{Co} / \mathrm{N}-\mathrm{C} @ \mathrm{NiCO}_{2} \mathrm{O}_{4}, \mathrm{H}-\mathrm{NiCO}_{2} \mathrm{O}_{4}, \mathrm{Pt} / \mathrm{C}$, and Ir/C. The inset is $\Delta E$ for $\mathrm{H}-\mathrm{Co} / \mathrm{N}-\mathrm{C}$,

$\mathrm{H}-\mathrm{Co} / \mathrm{N}-\mathrm{C} @ \mathrm{NiCO}_{2} \mathrm{O}_{4}, \mathrm{H}-\mathrm{NiCO}_{2} \mathrm{O}_{4}$, and Pt-Ir/C.

$\mathrm{NiCo}_{2} \mathrm{O}_{4}$ is beneficial to the improvement of electrochemical properties (Table S2).

\section{Oxygen Electrocatalysis Performance}

The electrocatalytic activity of $\mathrm{H}-\mathrm{Co} / \mathrm{N}-\mathrm{C} @ \mathrm{NiCO}_{2} \mathrm{O}_{4}$ toward ORR is assessed with a conventional three-electrode cell. To better demonstrate the superior activity of $\mathrm{H}-\mathrm{Co} / \mathrm{N}$ $\mathrm{C} @ \mathrm{NiCo}_{2} \mathrm{O}_{4}$, the reference samples of $\mathrm{H}-\mathrm{Co} / \mathrm{N}-\mathrm{C}, \mathrm{H}-\mathrm{NiCo}_{2} \mathrm{O}_{4}$, and commercial $\mathrm{Pt} / \mathrm{C}$ were also evaluated and compared comprehensively. The raised cathodic peak at $\sim 0.75 \mathrm{~V}$ vs. RHE in an $\mathrm{O}_{2}$-saturated electrolyte compared to that in an $\mathrm{N}_{2}$-saturated electrolyte indicates effective ORR electrocatalytic activity of synthesized materials (Figure S8). LSV curves (Figure 3A) display more positive onset-potential ( $0.913 \mathrm{~V}$ vs. RHE), halfwave potential $(0.796 \mathrm{~V}$ vs. RHE), and larger diffusion-limited current density $\left(-4.96 \mathrm{~mA} \mathrm{~cm}^{-2}\right)$ of $\mathrm{H}-\mathrm{Co} / \mathrm{N}-\mathrm{C} @ \mathrm{NiCo}_{2} \mathrm{O}_{4}$ than that of $\mathrm{H}-\mathrm{Co} / \mathrm{N}-\mathrm{C}, \mathrm{H}-\mathrm{NiCo}_{2} \mathrm{O}_{4}$, and commercial Pt/C (Table S3). The rotating disk electrode (RDE) was carried out to calculate the reaction kinetic parameters via Koutecky-Levich (K-L) equation (Figure 3B and Figure S9). The calculated electron transfer number of $\mathrm{H}-\mathrm{Co} / \mathrm{N}-\mathrm{C} @ \mathrm{NiCo}_{2} \mathrm{O}_{4}$ is 3.99 , implying a direct four-electron process for ORR. Rotating ring disk electrode (RRDE) is operated to further quantify the ORR pathway of $\mathrm{H}-\mathrm{Co} / \mathrm{N}-\mathrm{C} @ \mathrm{NiCo}_{2} \mathrm{O}_{4}$ (Figure S10). The results indicate that the $\mathrm{HO}_{2}^{-}$yield of $\mathrm{H}-\mathrm{Co} / \mathrm{N}-\mathrm{C} @ \mathrm{NiCo}_{2} \mathrm{O}_{4}$ is the smallest among all synthesized materials. Besides, the average electron transfer number of $\mathrm{H}-\mathrm{Co} / \mathrm{N}-\mathrm{C} @ \mathrm{NiCo}_{2} \mathrm{O}_{4}$ is 3.61, larger than that of $\mathrm{H}$ $\mathrm{Co} / \mathrm{N}-\mathrm{C}$ (3.51) and $\mathrm{H}-\mathrm{NiCo}_{2} \mathrm{O}_{4}$ (2.40), which conform to the result obtained from $\mathrm{K}-\mathrm{L}$ plots.

The electrochemical double-layer capacitance $\left(C_{d l}\right)$ was deliberately measured to represent the relative electrochemical surface area (ECSA), which is linearly proportional to the number of active sites (Qiu et al., 2019) (Figure S11). The results in Figure 3C suggest that $\mathrm{H}-\mathrm{Co} / \mathrm{N}-\mathrm{C} @ \mathrm{NiCo}_{2} \mathrm{O}_{4}$ exhibits the smallest $C_{d l}$ value $\left(3.55 \mathrm{mF} \mathrm{cm}{ }^{-2}\right.$ ) compared with $\mathrm{H}-\mathrm{Co} / \mathrm{N}-$ $\mathrm{C}\left(11.67 \mathrm{mF} \mathrm{cm}{ }^{-2}\right)$ and $\mathrm{H}-\mathrm{NiCo}_{2} \mathrm{O}_{4}\left(3.56 \mathrm{mF} \mathrm{cm}{ }^{-2}\right)$. This indicates that the largely promoted ORR activity is due to the synergetic effect of $\mathrm{Co} / \mathrm{N}$-doped carbon and $\mathrm{NiCo}_{2} \mathrm{O}_{4}$. Besides 
the activity, stability is another important parameter for the practical applications of high-performance ORR electrocatalysts. The $\mathrm{H}-\mathrm{Co} / \mathrm{N}-\mathrm{C} @ \mathrm{NiCo}_{2} \mathrm{O}_{4}$ shows an excellent durability with $92.3 \%$ retention after a continuous operation of $10,000 \mathrm{~s}$, much more stable than that of commercial $\mathrm{Pt} / \mathrm{C}$ catalysts (with only $77.5 \%$ retention) (Figure 3D), demonstrating a superb long-term stability of $\mathrm{H}-\mathrm{Co} / \mathrm{N}-\mathrm{C} @ \mathrm{NiCo}_{2} \mathrm{O}_{4}$ toward ORR.

Furthermore, the OER performances are also investigated in $\mathrm{KOH}$ solution with $90 \%$ iR-compensation (Figure 3E). The $\mathrm{H}-$ $\mathrm{Co} / \mathrm{N}-\mathrm{C} @ \mathrm{NiCo}_{2} \mathrm{O}_{4}$ displays a relatively low onset potential with an overpotential of $386 \mathrm{mV}$ to achieve the current density of $10 \mathrm{~mA} \mathrm{~cm}^{-2}$, far superior to $\mathrm{H}-\mathrm{Co} / \mathrm{N}-\mathrm{C}(552 \mathrm{mV}), \mathrm{H}-\mathrm{NiCo}_{2} \mathrm{O}_{4}$ $(405 \mathrm{mV})$, and commercial $\mathrm{Ir} / \mathrm{C}(567 \mathrm{mV})$. Besides, $\mathrm{H}-\mathrm{Co} / \mathrm{N}-$ $\mathrm{C} @ \mathrm{NiCo}_{2} \mathrm{O}_{4}$ presents a Tafel slope of $94 \mathrm{mV} \mathrm{dec}^{-1}$, much smaller than that of $\mathrm{H}-\mathrm{Co} / \mathrm{N}-\mathrm{C}\left(303 \mathrm{mV} \mathrm{dec}{ }^{-1}\right), \mathrm{H}-\mathrm{NiCo}_{2} \mathrm{O}_{4}(299 \mathrm{mV}$ $\left.\mathrm{dec}^{-1}\right)$, and commercial $\mathrm{Ir} / \mathrm{C}\left(326 \mathrm{mV} \mathrm{dec}^{-1}\right)$, and reveals much faster reaction kinetics for OER (Figure 3F). Furthermore, the stability of $\mathrm{H}-\mathrm{Co} / \mathrm{N}-\mathrm{C} @ \mathrm{NiCo}_{2} \mathrm{O}_{4}$ for $\mathrm{OER}$ was investigated (Figure 3G). Although performance has declined to some extent, which is the result of the dissolution of materials from carbon cloth due to the bubble formation, the H-Co/N-C@NiCo $\mathrm{O}_{4}$ still retains $68.7 \%$ of the initial performance after continuous operation of $18 \mathrm{~h}$, better than that of $\mathrm{Ir} / \mathrm{C}$ catalysts (with only $34.8 \%$ retention after $15 \mathrm{~h}$ ), demonstrating the promising potential to replace noble metal catalysts for both ORR and OER. Additionally, the robust stability of $\mathrm{H}-\mathrm{Co} / \mathrm{N}-\mathrm{C} @ \mathrm{NiCo}_{2} \mathrm{O}_{4}$ is verified by TEM, HRTEM, and XPS. As can be seen from Figure S12, the structure and composition retain their original state after all electrochemical tests, demonstrating the superior stability of $\mathrm{H}-\mathrm{Co} / \mathrm{N}-\mathrm{C} @ \mathrm{NiCo}_{2} \mathrm{O}_{4}$. XPS measurement of $\mathrm{H}$ $\mathrm{Co} / \mathrm{N}-\mathrm{C} @ \mathrm{NiCo}_{2} \mathrm{O}_{4}$ after all electrochemical tests exhibits some predictable changes (Figure S13). Namely, the valence state of Co and $\mathrm{Ni}$ has increased after all electrochemical tests, which is an unavoidable result after working at a high potential (Cao et al., 2018; Gu et al., 2018).

The overall oxygen electrode activity for both ORR and OER is evaluated by the difference between the overpotential measured at a current density of $10 \mathrm{~mA} \mathrm{~cm}^{-2}$ for OER and half-wave potential for ORR $\left(\Delta E=E_{j 10}-E_{1 / 2}\right)$. Remarkably, the $\mathrm{H}-\mathrm{Co} / \mathrm{N}-\mathrm{C} @ \mathrm{NiCo}_{2} \mathrm{O}_{4}$ displays a $\Delta E$ of $0.82 \mathrm{~V}$, much lower than that of $\mathrm{H}-\mathrm{Co} / \mathrm{N}-\mathrm{C}(0.98 \mathrm{~V}), \mathrm{H}-\mathrm{NiCo}_{2} \mathrm{O}_{4}(0.90 \mathrm{~V})$, commercial Pt-Ir/C $(0.89 \mathrm{~V})$ (Figure 3H), and most reported bi-functional electrocatalysts (Table S4). The electrochemical performance of $\mathrm{H}-\mathrm{Co} / \mathrm{N}-\mathrm{C} @ \mathrm{NiCo}_{2} \mathrm{O}_{4}$ and the control samples is
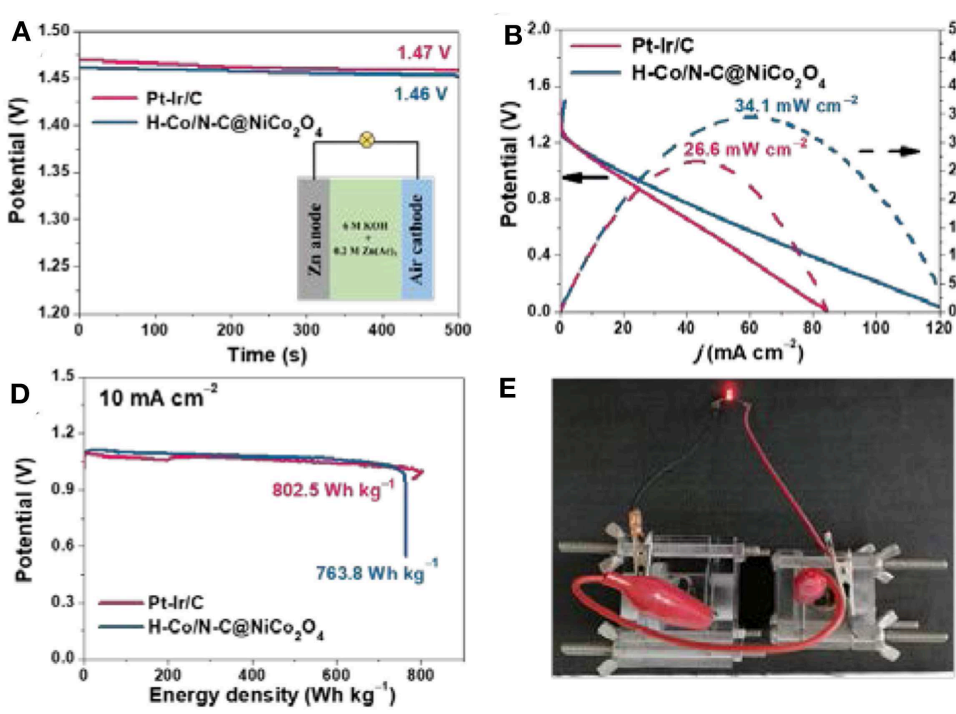

E
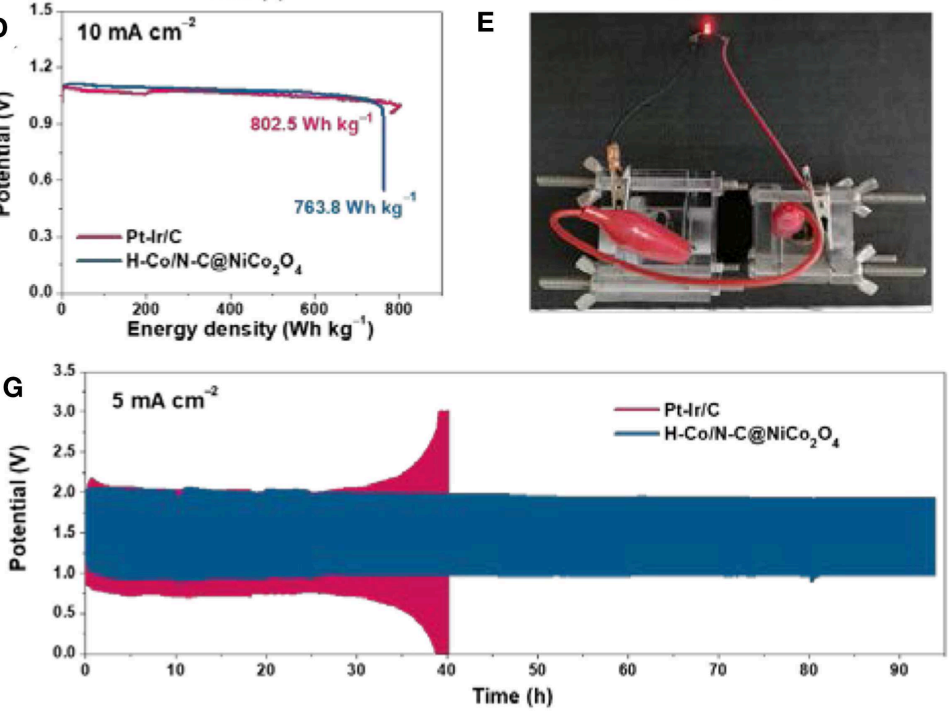
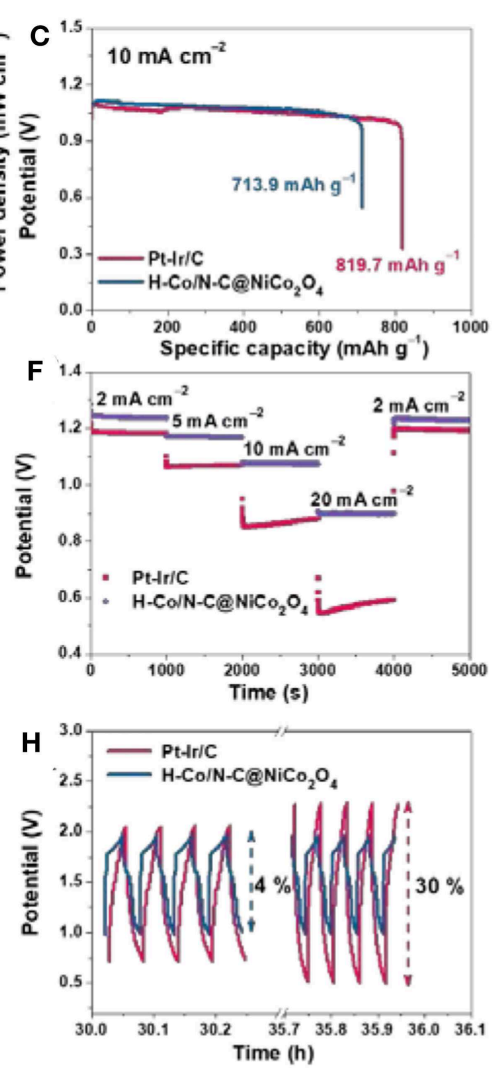

FIGURE 4 | (A) Open-circuit plots (inset picture is the schematic representation of Zn-air battery), (B) polarization curves and corresponding power density plots of the $\mathrm{Zn}$-air battery based on $\mathrm{H}-\mathrm{Co} / \mathrm{N}-\mathrm{C} @ \mathrm{NiCO}_{2} \mathrm{O}_{4}$ and Pt-Ir/C. The calculated (C) specific capacity and (D) energy density of the Zn-air battery based on $\mathrm{H}-\mathrm{Co} / \mathrm{N}-\mathrm{C} @ \mathrm{NiCO}_{2} \mathrm{O}_{4}$ and Pt-Ir/C. (E) Photograph of a red LED powered by two Zn-air battery based on $\mathrm{H}-\mathrm{Co} / \mathrm{N}-\mathrm{C} @ \mathrm{NiCO} 2 \mathrm{O}_{4}$ in series. (F) Galvanostatic discharge curves, (G,H) galvanostatic discharge-charge cycling curves of $\mathrm{Zn}$-air battery based on $\mathrm{H}-\mathrm{Co} / \mathrm{N}-\mathrm{C} @ \mathrm{NiCO}_{2} \mathrm{O}_{4}$ and Pt-Ir/C. 
further investigated by electrochemical impedance spectroscopy measurements (Figure S14). From the Nyquist plots, the charge transfer resistance $\left(R_{\mathrm{ct}}=\sim 9.8 \Omega\right)$ of $\mathrm{H}-\mathrm{Co} / \mathrm{N}-\mathrm{C} @ \mathrm{NiCo}_{2} \mathrm{O}_{4}$ and $\mathrm{H}-\mathrm{Co} / \mathrm{N}-\mathrm{C}$ is nearly the same $\left(R_{\mathrm{ct}}=\sim 9.8 \Omega\right)$ at high frequency due to the excellent conductivity of $\mathrm{N}$-doped carbon. However, the pure $\mathrm{H}-\mathrm{NiCo}_{2} \mathrm{O}_{4}$ shows relative sluggish electron transfer ability $\left(R_{\mathrm{ct}}=\sim 12.2 \Omega\right)$ because of the limited conductivity. Moreover, the straight line at low frequency shows significantly increased slope for $\mathrm{H}-\mathrm{Co} / \mathrm{N}-\mathrm{C} @ \mathrm{NiCo}_{2} \mathrm{O}_{4}$ than $\mathrm{H}-\mathrm{Co} / \mathrm{N}-\mathrm{C}$, indicating the faster mass diffusion behavior benefiting from this unique hierarchical structure. Although the mass diffusion ability is not as good as that of $\mathrm{H}-\mathrm{NiCO}_{2} \mathrm{O}_{4}$, the better ORR performance of $\mathrm{H}-\mathrm{Co} / \mathrm{N}-\mathrm{C} @ \mathrm{NiCo}_{2} \mathrm{O}_{4}$ indicates that the balance between mass diffusion and charge transfer is crucial for the performance of electrocatalysts.

The excellent ORR and OER performance of $\mathrm{H}-\mathrm{Co} / \mathrm{N}$ $\mathrm{C@NiCo} 2 \mathrm{O}_{4}$ benefits from the advantages of promoted surface reaction, enhanced charge transfer property, and improved mass diffusion process. As shown in Figure S15, the LSV plots of $\mathrm{H}-\mathrm{Co} / \mathrm{N}-\mathrm{C} @ \mathrm{NiCo}_{2} \mathrm{O}_{4}, \mathrm{H}-\mathrm{Co} / \mathrm{N}-\mathrm{C}$, and $\mathrm{H}-\mathrm{NiCo}_{2} \mathrm{O}_{4}$ for ORR were normalized by their ECSA. The current density of $\mathrm{H}-\mathrm{Co} / \mathrm{N}-\mathrm{C} @ \mathrm{NiCo}_{2} \mathrm{O}_{4}\left(-0.274 \mathrm{~mA} \mathrm{~cm} \mathrm{mF}^{-1}\right)$ is much higher than that of $\mathrm{H}-\mathrm{Co} / \mathrm{N}-\mathrm{C}\left(-0.081 \mathrm{~mA} \mathrm{~cm}^{2} \mathrm{mF}^{-1}\right)$ and $\mathrm{H}-\mathrm{NiCo}_{2} \mathrm{O}_{4}\left(-0.195 \mathrm{~mA} \mathrm{~cm} \mathrm{mF}^{-1}\right)$, indicating high intrinsic activity for ORR owing to the synergistic effect between the compositions (Figure 3C and Figure S7). Second, the combination of $\mathrm{H}-\mathrm{Co} / \mathrm{N}-\mathrm{C}$ and $\mathrm{NiCo}_{2} \mathrm{O}_{4}$ renders fast electron transfer between active sites and current collector, which can be verified by the lower resistance of $\sim 9.8 \Omega$ (Figure S14). Last but not least, the unique hierarchical hollow structure also ensures an efficient mass diffusion process, which accelerates the transport and adsorption of reactants to active sites and thus leads to a high reaction kinetics

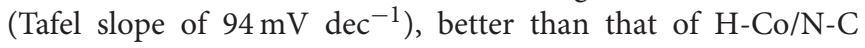

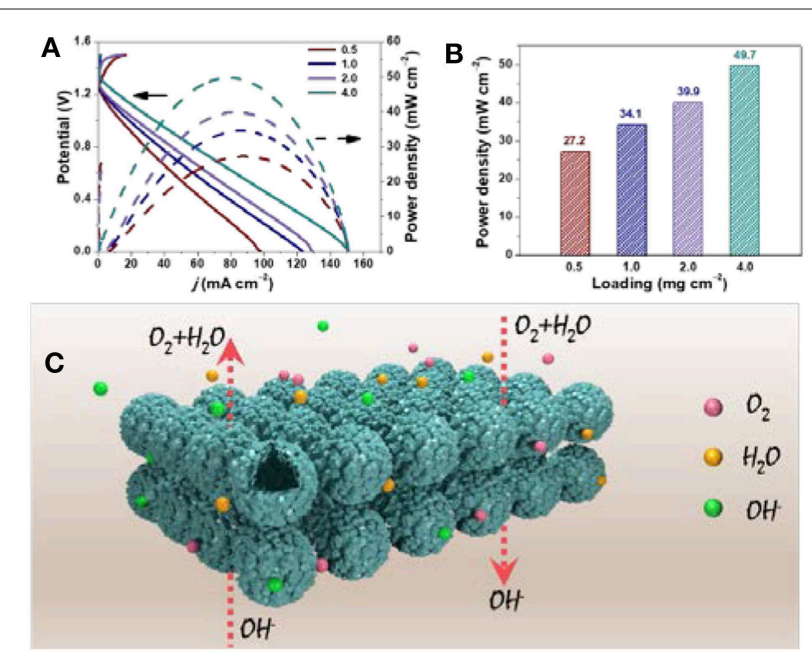

FIGURE 5 | (A) Polarization curves and corresponding power density plots of $\mathrm{H}-\mathrm{Co} / \mathrm{N}-\mathrm{C} @ \mathrm{NiCO}_{2} \mathrm{O}_{4}$ with different mass loading. (B) The histogram of power density vs. mass-loading. (C) Schematic illustration of electrochemical process on $\mathrm{H}-\mathrm{Co} / \mathrm{N}-\mathrm{C} @ \mathrm{NiCO}_{2} \mathrm{O}_{4}$. $\left(303 \mathrm{mV} \mathrm{dec}^{-1}\right)$ and $\mathrm{H}-\mathrm{NiCo}_{2} \mathrm{O}_{4}\left(299 \mathrm{mV} \mathrm{dec}^{-1}\right)$ (Figure 3F and Figure S14).

Encouraged by the superior electrochemical activity under basic medium, the ORR performance of $\mathrm{H}-\mathrm{Co} / \mathrm{N}-\mathrm{C} @ \mathrm{NiCo}_{2} \mathrm{O}_{4}$ was also investigated in acidic medium (Figure S16). The $\mathrm{H}$ $\mathrm{Co} / \mathrm{N}-\mathrm{C} @ \mathrm{NiCo}_{2} \mathrm{O}_{4}$ delivers acceptable ORR performance with a diffusion-limited current density of $-3.06 \mathrm{~mA} \mathrm{~cm}^{-2}$, better than that of $\mathrm{H}-\mathrm{NiCo}_{2} \mathrm{O}_{4}\left(-2.47 \mathrm{~mA} \mathrm{~cm}^{-2}\right)$ and $\mathrm{H}-\mathrm{Co} / \mathrm{N}-\mathrm{C}$ $\left(-2.95 \mathrm{~mA} \mathrm{~cm}^{-2}\right)$. However, due to the instability behavior of $\mathrm{NiCo}_{2} \mathrm{O}_{4}$ under acidic conditions, this performance cannot be well-maintained for a long lifespan.

\section{Zn-Air Battery Performance}

Motivated by the superior electrocatalytic activity for both ORR and OER, the feasibility of $\mathrm{H}-\mathrm{Co} / \mathrm{N}-\mathrm{C} @ \mathrm{NiCo}_{2} \mathrm{O}_{4}$ as the air cathode in $\mathrm{Zn}$-air battery was further studied. The open-circuit voltage of $\mathrm{Zn}$-air battery based on $\mathrm{H}-\mathrm{Co} / \mathrm{N}-\mathrm{C} @ \mathrm{NiCo}_{2} \mathrm{O}_{4}$ is $1.46 \mathrm{~V}$ (Figure 4A), comparable to that of the $\mathrm{Zn}$-air battery based on commercial Pt-Ir/C $(1.47 \mathrm{~V})$. The discharge polarization curve of the $\mathrm{Zn}$-air battery based on $\mathrm{H}-\mathrm{Co} / \mathrm{N}-\mathrm{C} @ \mathrm{NiCo}_{2} \mathrm{O}_{4}$ reveals a high peak power density of $34.1 \mathrm{~mW} \mathrm{~cm}^{-2}$, which is superior to that of the $\mathrm{Zn}$-air battery based on commercial Pt$\mathrm{Ir} / \mathrm{C}\left(26.6 \mathrm{~mW} \mathrm{~cm}^{-2}\right)$ (Figure 4B). Moreover, the $\mathrm{Zn}$-air battery based on $\mathrm{H}-\mathrm{Co} / \mathrm{N}-\mathrm{C} @ \mathrm{NiCo}_{2} \mathrm{O}_{4}$ delivers high specific capacity (713.9 $\mathrm{mAh} \mathrm{g}^{-1}$ ) and energy density (763.8 $\mathrm{Wh} \mathrm{kg}^{-1}$ ) at a current density of $10 \mathrm{~mA} \mathrm{~cm}{ }^{-2}$, respectively, close to that of Pt$\mathrm{Ir} / \mathrm{C}\left(819.7 \mathrm{mAh} \mathrm{g}^{-1}\right.$ and $802.5 \mathrm{Wh} \mathrm{kg}^{-1}$ ) (Figures 4C,D). A light-emitting diode could be effectively powered by two $\mathrm{Zn}$ air batteries in series (Figure 4E). The discharge curves of $\mathrm{Zn}$ air battery based on $\mathrm{H}-\mathrm{Co} / \mathrm{N}-\mathrm{C} @ \mathrm{NiCo}_{2} \mathrm{O}_{4}$ and commercial Pt$\mathrm{Ir} / \mathrm{C}$ are conducted at various current densities from 2 to $20 \mathrm{~mA}$ $\mathrm{cm}^{-2}$. Compared with the commercial Pt-Ir/C electrode, the $\mathrm{H}-\mathrm{Co} / \mathrm{N}-\mathrm{C} @ \mathrm{NiCo}_{2} \mathrm{O}_{4}$ electrode shows higher discharge voltages and relatively stable discharge performance, indicating the better ORR activity, and reversible capacity (Figure 4F). Moreover, the $\mathrm{H}-\mathrm{Co} / \mathrm{N}-\mathrm{C} @ \mathrm{NiCo}_{2} \mathrm{O}_{4}$ electrode shows excellent stability as there is only a small change in charge and discharge voltages (voltage gap increases by $4 \%$ ) over $90 \mathrm{~h}$ in the long-term cycling tests, while the commercial $\mathrm{Pt}-\mathrm{Ir} / \mathrm{C}$ electrode shows a large change (voltage gap increases by $30 \%$ ) after $36 \mathrm{~h}$, which indicates the excellent stability and rechargeability of the $\mathrm{Zn}$-air battery based on $\mathrm{H}-\mathrm{Co} / \mathrm{N}-\mathrm{C} @ \mathrm{NiCo}_{2} \mathrm{O}_{4}$ (Figures 4G,H).

A most typical strategy to achieve high performance of a device system is to increase mass loading of electrocatalysts (Liu et al., 2018). However, the issues of physical limits to mass loading and plateau effect in performance are all inevitable (Xie et al., 2019). In this work, we further study the battery performance of $\mathrm{H}-\mathrm{Co} / \mathrm{N}-\mathrm{C} @ \mathrm{NiCo}_{2} \mathrm{O}_{4}$ under high mass loading. Obviously, the peak power density of $\mathrm{H}$ $\mathrm{Co} / \mathrm{N}-\mathrm{C} @ \mathrm{NiCo}_{2} \mathrm{O}_{4}$ gradually increases from 27.2 to $49.7 \mathrm{~mW}$ $\mathrm{cm}^{-2}$ with the increasing mass loading from 0.5 to $4 \mathrm{mg}$ $\mathrm{cm}^{-2}$ (Figure 5A and Table S5), which demonstrates that most active sites could participate into the reaction in spite of the electrocatalyst layers becoming thicker (Figure 5B). This high mass-loading-independent performance of $\mathrm{H}-\mathrm{Co} / \mathrm{N}$ $\mathrm{C@NiCo} 2 \mathrm{O}_{4}$ is largely ascribed to the following hierarchical structure features and compositional merits. First, the synergetic 
effect of $\mathrm{Co} / \mathrm{N}-\mathrm{C}$ and $\mathrm{NiCo}_{2} \mathrm{O}_{4}$ guarantees promising bifunctional performance for both ORR and OER $(\Delta E=0.82 \mathrm{~V})$. Second, the hierarchical structure provides large surface area, which enables fast charge transfer and more active sites accessible to electrolyte and $\mathrm{O}_{2}$. Third, the hollow microsphere with sufficient internal void space and abundant mesopores serves as an efficient buffering reservoir and facilitates the fast diffusion of electrolyte. Last, this unique microsphere structure ensures good mechanical stability (more than $90 \mathrm{~h}$ ) and minimizes particle aggregation, which is important to the practical application in ZAB (Figure 5C).

\section{CONCLUSION}

In summary, a hierarchical hollow structure $\mathrm{H}-\mathrm{Co} / \mathrm{N}$ $\mathrm{C} @ \mathrm{NiCo}_{2} \mathrm{O}_{4}$ microsphere with cobalt/nitrogen-doped carbon as core and Ni-Co mixed metal oxides as shell has been successfully synthesized via a facile self-template approach. Benefiting from the advantages of this structure and composition, the $\mathrm{H}-\mathrm{Co} / \mathrm{N}-\mathrm{C} @ \mathrm{NiCo}_{2} \mathrm{O}_{4}$ exhibits superior electrocatalytic activity and long-term stability for both ORR and OER. Furthermore, $\mathrm{H}-\mathrm{Co} / \mathrm{N}-\mathrm{C} @ \mathrm{NiCo}_{2} \mathrm{O}_{4}$ is constructed as an air electrode for rechargeable $\mathrm{ZAB}$, delivering a high power density and long cycling stability. The good linear relationship between the power density and various mass loading of $\mathrm{H}-\mathrm{Co} / \mathrm{N}-\mathrm{C} @ \mathrm{NiCo}_{2} \mathrm{O}_{4}$ on the electrode demonstrates that the performance has been wellmaintained even under high dense packing of catalysts,

\section{REFERENCES}

Aijaz, A., Masa, J., Rosler, C., Xia, W., Weide, P., Botz, A. J., et al. (2016). Co@ $\mathrm{Co}_{3} \mathrm{O}_{4}$ encapsulated in carbon nanotube-grafted nitrogendoped carbon polyhedra as an advanced bifunctional oxygen electrode. Angew. Chem. Int. Ed. 55, 4087-4091. doi: 10.1002/anie. 201509382

Amiinu, I. S., Liu, X., Pu, Z., Li, W., Li, Q., Zhang, J., et al. (2018). From 3D ZIF nanocrystals to Co-Nx/C nanorod array electrocatalysts for ORR, OER, and Zn-air batteries. Adv. Funct. Mater. 28, 1704638-1704646. doi: 10.1002/adfm.201704638

Asset, T., Job, N., Busby, Y., Crisci, A., Martin, V., Stergiopoulos, V., et al. (2018). Porous hollow PtNi/C electrocatalysts: carbon support considerations to meet performance and stability requirements. ACS Catal. 8, 893-903. doi: $10.1021 /$ acscatal.7b03539

Audichon, T., Napporn, T. W., Canaff, C., Morais, C., Comminges, C., and Kokoh, K. B. (2016). $\mathrm{IrO}_{2}$ coated on $\mathrm{RuO}_{2}$ as efficient and stable electroactive nanocatalysts for electrochemical water splitting. J. Phys. Chem. C 120, 2562-2573. doi: 10.1021/acs.jpcc.5b11868

Cao, C., Ma, D., Xu, Q., Wu, X., and Zhu, Q. (2018). Semisacrificial template growth of self-supporting MOF nanocomposite electrode for efficient electrocatalytic water oxidation. Adv. Funct. Mater. 29, 1807418-1807425. doi: 10.1002/adfm.201807418

Chen, T., Zhang, Z., Cheng, B., Chen, R., Hu, Y., Ma, L., et al. (2017). Self-templated formation of interlaced carbon nanotubes threaded hollow $\mathrm{Co}_{3} \mathrm{~S}_{4}$ nanoboxes for high-rate and heat-resistant lithium-sulfur batteries. J. Am. Chem. Soc. 139, 12710-12715. doi: 10.1021/jacs.7b06973

Chen, X., Zhou, Z., Karahan, H. E., Shao, Q., Wei, L., and Chen, Y. (2018). Recent advances in materials and design of electrochemically rechargeable zinc-air batteries. Small 14, 1801929-1801957. doi: 10.1002/smll. 201801929 which offers a new pathway for the practical applications in $\mathrm{ZAB}$.

\section{DATA AVAILABILITY STATEMENT}

All datasets generated for this study are included in the manuscript/Supplementary Files.

\section{AUTHOR CONTRIBUTIONS}

MS conceived and supervised the project. YS and WX performed the experiment, characterized the materials, and wrote the manuscript supervised by JG and MS. SL performed the SEM characterization. All authors discussed the results and commented on the paper.

\section{FUNDING}

This work was supported by the National Natural Science Foundation of China (21601011 and 21521005) and the Fundamental Research Funds for the Central Universities (XK1802-6).

\section{SUPPLEMENTARY MATERIAL}

The Supplementary Material for this article can be found online at: https://www.frontiersin.org/articles/10.3389/fmats. 2019.00261/full\#supplementary-material

Cui, B., Lin, H., Liu, Y., Li, J.-B., Sun, P., Zhao, X., et al. (2009). Photophysical and photocatalytic properties of core-ring structured $\mathrm{NiCo}_{2} \mathrm{O}_{4}$ nanoplatelets. J. Phys. Chem. C 113, 14083-14087. doi: 10.1021/jp900028t

Ferrero, G. A., Fuertes, A. B., Sevilla, M., and Titirici, M. M. (2016). Efficient metal-free $\mathrm{N}$-doped mesoporous carbon catalysts for ORR by a template-free approach. Carbon N. Y. 106, 179-187. doi: 10.1016/j.carbon.2016.04.080

Fu, Y., Yu, H., Jiang, C., Zhang, T., Zhan, R., Li, X., et al. (2018). NiCo alloy nanoparticles decorated on $\mathrm{N}$-doped carbon nanofibers as highly active and durable oxygen electrocatalyst. Adv. Funct. Mater. 28, 1705094-1705103. doi: 10.1002/adfm.201705094

Ganesan, P., Prabu, M., Sanetuntikul, J., and Shanmugam, S. (2015). Cobalt sulfide nanoparticles grown on nitrogen and sulfur codoped graphene oxide: an efficient electrocatalyst for oxygen reduction and evolution reactions. ACS Catal. 5, 3625-3637. doi: 10.1021/acscatal.5b00154

Gu, C., Hu, S., Zheng, X., Gao, M. R., Zheng, Y. R., Shi, L., et al. (2018). Synthesis of sub-2 nm iron-doped $\mathrm{NiSe}_{2}$ nanowires and their surface-confined oxidation for oxygen evolution catalysis. Angew. Chem. Int. Ed. 57, 4020-4024. doi: 10.1002/anie.201800883

Guan, B. Y., Yu, L., and Lou, X. W. D. (2017). Formation of single-holed cobalt/Ndoped carbon hollow particles with enhanced electrocatalytic activity toward oxygen reduction reaction in alkaline media. Adv. Sci. 4, 1700247-1700252. doi: 10.1002/advs.201700247

Guan, C., Liu, X., Ren, W., Li, X., Cheng, C., and Wang, J. (2017). Rational design of metal-organic framework derived hollow $\mathrm{NiCo}_{2} \mathrm{O}_{4}$ arrays for flexible supercapacitor and electrocatalysis. Adv. Energy Mater. 7, 1602391-1602398. doi: 10.1002/aenm.201602391

Guo, Y., Yuan, P., Zhang, J., Xia, H., Cheng, F., Zhou, M., et al. (2018). Co 2 P-CoN double active centers confined in $\mathrm{N}$-doped carbon nanotube: heterostructural engineering for trifunctional catalysis toward HER, ORR, OER, and Zn-air batteries driven water splitting. Adv. Funct. Mater. 28, 1805641-1805649. doi: 10.1002/adfm.201805641 
Guo, Z., Wang, F., Xia, Y., Li, J., Tamirat, A. G., Liu, Y., et al. (2018). In situ encapsulation of core-shell-structured $\mathrm{Co@} \mathrm{Co}_{3} \mathrm{O}_{4}$ into nitrogen-doped carbon polyhedra as a bifunctional catalyst for rechargeable $\mathrm{Zn}$-air batteries. J. Mater. Chem. A 6, 1443-1453. doi: 10.1039/C7TA09958D

Hang, C., Zhang, J., Zhu, J., Li, W., Kou, Z., and Huang, Y. (2018). In situ exfoliating and generating active sites on graphene nanosheets strongly coupled with carbon fiber toward self-standing bifunctional cathode for rechargeable Zn-air batteries. Adv. Energy Mater. 8, 1703539-1703547. doi: 10.1002/aenm.201703539

Jia, G., Zhang, W., Fan, G., Li, Z., Fu, D., Hao, W., et al. (2017). Threedimensional hierarchical architectures derived from surface-mounted metalorganic framework membranes for enhanced electrocatalysis. Angew. Chem. Int. Ed. 56, 13781-13785. doi: 10.1002/anie.201708385

Jiang, H., Liu, Y., Li, W., and Li, J. (2018). Co nanoparticles confined in 3D nitrogen-doped porous carbon foams as bifunctional electrocatalysts for long-life rechargeable Zn-air batteries. Small 14, 1703739-1703748. doi: 10.1002/smll.201703739

Jiang, R., Li, L., Sheng, T., Hu, G., Chen, Y., and Wang, L. (2018). Edge-site engineering of atomically dispersed $\mathrm{Fe}-\mathrm{N}_{4}$ by selective $\mathrm{C}-\mathrm{N}$ bond cleavage for enhanced oxygen reduction reaction activities. J. Am. Chem. Soc. 140, 11594-11598. doi: 10.1021/jacs.8b07294

Kaneti, Y. V., Dutta, S., Hossain, M. S. A., Shiddiky, M. J. A., Tung, K. L., Shieh, F. K., et al. (2017). Strategies for improving the functionality of zeolitic imidazolate frameworks: tailoring nanoarchitectures for functional applications. Adv. Mater. Weinheim. 29, 1700213-1700243. doi: 10.1002/adma.201700213

Lee, J., Ha, J. U., Choe, S., Lee, C. S., and Shim, S. E. (2006). Synthesis of highly monodisperse polystyrene microspheres via dispersion polymerization using an amphoteric initiator. J. Colloid Interf. Sci. 298, 663-671. doi: $10.1016 /$ j.jcis.2006.01.001

Lee, J. S., Tai Kim, S., Cao, R., Choi, N. S., Liu, M., Lee, K. T., et al. (2011). Metal-air batteries with high energy density: Li-air versus $\mathrm{Zn}$-air. Adv. Energy Mater. 1, 34-50. doi: 10.1002/aenm.201000010

Li, J., Lu, S. Q., Huang, H. L., Liu, D. H., Zhuang, Z. B., and Zhong, C. L. (2018). ZIF-67 as continuous self-sacrifice template derived $\mathrm{NiCo}_{2} \mathrm{O}_{4} / \mathrm{Co}, \mathrm{N}-\mathrm{CNTs}$ nanocages as efficient bifunctional electrocatalysts for rechargeable Zn-air batteries. ACS Sustainable Chem. Eng. 6, 10021-10029. doi: 10.1021/acssuschemeng.8b01332

Li, T., Lu, Y., Zhao, S., Gao, Z., and Song, Y. (2018). $\mathrm{Co}_{3} \mathrm{O}_{4}$-doped Co/CoFe nanoparticles encapsulated in carbon shells as bifunctional electrocatalysts for rechargeable Zn-Air batteries. J. Mater. Chem. A 6, 3730-3737. doi: 10.1039/C7TA11171A

Li, Y., and Dai, H. (2014). Recent advances in zinc-air batteries. Chem. Soc. Rev. 43, 5257-5275. doi: 10.1039/C4CS00015C

Li, Y., Li, F. M., Meng, X. N., Li, S. N., Zeng, J. H., and Chen, Y. (2018). Ultrathin $\mathrm{Co}_{3} \mathrm{O}_{4}$ nanomeshes for the oxygen evolution reaction. ACS Catal. 8, 1913-1920. doi: 10.1021/acscatal.7b03949

Li, Z., Shao, M., An, H., Wang, Z., Xu, S., Wei, M., et al. (2015). Fast electrosynthesis of Fe-containing layered double hydroxide arrays toward highly efficient electrocatalytic oxidation reactions. Chem. Sci. 6, 6624-6631. doi: 10.1039/C5SC02417J

Li, Z., Shao, M., Zhou, L., Zhang, R., Zhang, C., Wei, M., et al. (2016). Directed growth of metal-organic frameworks and their derived carbon-based network for efficient electrocatalytic oxygen reduction. Adv. Mater. Weinheim. 28, 2337-2344. doi: 10.1002/adma.201505086

Liang, Q., Jin, H., Wang, Z., Xiong, Y., Yuan, S., Zeng, X., et al. (2019). Metal-organic frameworks derived reverse-encapsulation Co-NC@ $\mathrm{Mo}_{2} \mathrm{C}$ complex for efficient overall water splitting. Nano Energy 57, 746-752. doi: 10.1016/j.nanoen.2018.12.060

Liu, J., Zhu, D., Zheng, Y., Vasileff, A., and Qiao, S. Z. (2018). Self-supported earthabundant nanoarrays as efficient and robust electrocatalysts for energy-related reactions. ACS Catal. 8, 6707-6732. doi: 10.1021/acscatal.8b01715

Liu, Y., Dong, P., Li, M., Wu, H., Zhang, C., Han, L., et al. (2019). Cobalt nanoparticles encapsulated in nitrogen-doped carbon nanotube as bifunctional-catalyst for rechargeable Zn-air batteries. Front. Mater. 6, 85-101. doi: 10.3389/fmats.2019.00085

Meng, F. L., Liu, K. H., Zhang, Y., Shi, M. M., Zhang, X. B., Yan, J. M., et al. (2018). Recent advances toward the rational design of efficient bifunctional air electrodes for rechargeable Zn-air batteries. Small 14, 1703843-1703862. doi: $10.1002 / \mathrm{smll} .201703843$

Ni, B., Ouyang, C., Xu, X., Zhuang, J., and Wang, X. (2017). Modifying commercial carbon with trace amounts of ZIF to prepare derivatives with superior ORR activities. Adv. Mater. Weinheim. 29, 1701354-1701360. doi: 10.1002/adma.201701354

Park, J., Park, M., Nam, G., Kim, M. G., and Cho, J. (2017). Unveiling the catalytic origin of nanocrystalline yttrium ruthenate pyrochlore as a bifunctional electrocatalyst for Zn-air batteries. Nano Lett. 17, 3974-3981. doi: 10.1021/acs.nanolett.7b01812

Peng, S., Gong, F., Li, L., Yu, D., Ji, D., Zhang, T., et al. (2018). Necklacelike multishelled hollow spinel oxides with oxygen vacancies for efficient water electrolysis. J. Am. Chem. Soc. 140, 13644-13653. doi: 10.1021/jacs. 8 b05134

Prabu, M., Ketpang, K., and Shanmugam, S. (2014). Hierarchical nanostructured $\mathrm{NiCo}_{2} \mathrm{O}_{4}$ as an efficient bifunctional non-precious metal catalyst for rechargeable zinc-air batteries. Nanoscale 6, 3173-3181. doi: 10.1039/c3nr05835b

Qiu, H. J., Du, P., Hu, K., Gao, J., Li, H., Liu, P., et al. (2019). Metal and nonmetal codoped 3D nanoporous graphene for efficient bifunctional electrocatalysis and rechargeable Zn-air batteries. Adv. Mater. Weinheim. 31, 1900843-1900849. doi: 10.1002/adma.201900843

Shang, L., Yu, H., Huang, X., Bian, T., Shi, R., Zhao, Y., et al. (2016). Well-dispersed ZIF-derived Co,N-Co-doped carbon nanoframes through mesoporous-silicaprotected calcination as efficient oxygen reduction electrocatalysts. Adv. Mater. Weinheim. 28, 1668-1674. doi: 10.1002/adma.201505045

Umeshbabu, E., Rajeshkhanna, G., Justin, P., and Rao, G. R. (2015). Synthesis of mesoporous $\mathrm{NiCo}_{2} \mathrm{O}_{4}$-rGO by a solvothermal method for charge storage applications. RSC Adv. 5, 66657-66666. doi: 10.1039/C5RA11239G

Wang, H. F., Tang, C., and Zhang, Q. (2018). A review of preciousmetal-free bifunctional oxygen electrocatalysts: rational design and applications in Zn-air batteries. Adv. Funct. Mater. 28, 1803329-1803350. doi: 10.1002/adfm.201803329

Wang, T., Kou, Z., Mu, S., Liu, J., He, D., Amiinu, I. S., et al. (2018). 2D dual-metal zeolitic-imidazolate-framework-(ZIF)-derived bifunctional air electrodes with ultrahigh electrochemical properties for rechargeable zinc-air batteries. $A d v$. Funct. Mater. 28, 1705048-1705056. doi: 10.1002/adfm.201705048

Wang, Z., Jin, H., Meng, T., Liao, K., Meng, W., Yang, J., et al. (2018). Fe, $\mathrm{Cu}$-coordinated ZIF-derived carbon framework for efficient oxygen reduction reaction and zinc-air batteries. Adv. Funct. Mater. 28, 1802596-1802603. doi: 10.1002/adfm.201802596

Wu, J., Zhang, J., Peng, Z., Yang, S., Wagner, F. T., and Yang, H. (2010). Truncated octahedral $\mathrm{Pt}_{3} \mathrm{Ni}$ oxygen reduction reaction electrocatalysts. J. Am. Chem. Soc. 132, 4984-4985. doi: 10.1021/ja100571h

Wu, R., Xiao, B., Gao, Q., Zheng, Y. R., Zheng, X. S., Zhu, J. F., et al. (2018). A janus nickel cobalt phosphide catalyst for high-efficiency neutralpH water splitting. Angew. Chem. 57, 15445-15449. doi: 10.1002/anie. 201808929

Xie, W. F., Li, Z. H., Jiang, S., Li, J. B., Shao, M. F., and Wei, M. (2019). Mass-loading independent electrocatalyst with high performance for oxygen reduction reaction and $\mathrm{Zn}$-air battery based on Co-N-codoped carbon nanotube assembled microspheres. Chem. Eng. J. 373, 734-743. doi: 10.1016/j.cej.2019.04.066

Yang, Q. H., Li, Z. H., Zhang, R. K., Zhou, L., Shao, M. F., and Wei, M. (2017) Carbon modified transition metal oxides/hydroxides nanoarrays toward highperformance flexible all-solid-state supercapacitors. Nano Energy 41, 408-416. doi: 10.1016/j.nanoen.2017.09.049

Zhan, G., and Zeng, H. C. (2017). ZIF-67-derived nanoreactors for controlling product selectivity in $\mathrm{CO}_{2}$ hydrogenation. ACS Catal. 7, 7509-7519. doi: 10.1021/acscatal.7b01827

Zhang, C., Fu, L., Liu, N., Liu, M., Wang, Y., and Liu, Z. (2011). Synthesis of nitrogen-doped graphene using embedded carbon and nitrogen sources. Adv. Mater. Weinheim. 23, 1020-1024. doi: 10.1002/adma. 201004110

Zhang, G., and Lou, X. W. (2013). General solution growth of mesoporous $\mathrm{NiCo}_{2} \mathrm{O}_{4}$ nanosheets on various conductive substrates as high-performance electrodes for supercapacitors. Adv. Mater. Weinheim. 25, 976-979. doi: 10.1002/adma.201204128 
Zhang, J., Wang, T., Pohl, D., Rellinghaus, B., Dong, R., Liu, S., et al. (2016). Interface engineering of $\mathrm{MoS}_{2} / \mathrm{Ni}_{3} \mathrm{~S}_{2}$ heterostructures for highly enhanced electrochemical overall-water-splitting activity. Angew. Chem. Int. Ed. 55, 6702-6707. doi: 10.1002/anie.201602237

Zhao, D., Shui, J. L., Chen, C., Chen, X., Reprogle, B. M., Wang, D., et al. (2012). Iron imidazolate framework as precursor for electrocatalysts in polymer electrolyte membrane fuel cells. Chem. Sci. 3, 3200-3205. doi: $10.1039 / \mathrm{c} 2 \mathrm{sc} 20657 \mathrm{a}$

Zhou, L., Shao, M., Zhang, C., Zhao, J., He, S., Rao, D., et al. (2017b). Hierarchical CoNi-sulfide nanosheet arrays derived from layered double hydroxides toward efficient hydrazine electrooxidation. Adv. Mater. Weinheim. 29, 1604080-1604087. doi: 10.1002/adma.201604080

Zhou, L., Shao, M. F., Li, J. B., Jiang, S., Wei, M., and Duan, X. (2017a). Two-dimensional ultrathin arrays of CoP: electronic modulation toward high performance overall water splitting. Nano Energy 41, 583-590. doi: 10.1016/j.nanoen.2017.10.009
Zhou, W., Wu, X., Cao, X., Huang, X., Tan, C., Tian, J., et al. (2013) $\mathrm{Ni}_{3} \mathrm{~S}_{2}$ nanorods/Ni foam composite electrode with low overpotential for electrocatalytic oxygen evolution. Energy Environ. Sci. 6, 2921-2924. doi: $10.1039 /$ c3ee41572d

Conflict of Interest: The authors declare that the research was conducted in the absence of any commercial or financial relationships that could be construed as a potential conflict of interest.

Copyright (๑) 2019 Song, Xie, Li, Guo and Shao. This is an open-access article distributed under the terms of the Creative Commons Attribution License (CC BY). The use, distribution or reproduction in other forums is permitted, provided the original author(s) and the copyright owner(s) are credited and that the original publication in this journal is cited, in accordance with accepted academic practice. No use, distribution or reproduction is permitted which does not comply with these terms. 